(C) 2020. This manuscript version is made available under the CC-BY-NC-ND 4.0 license http://creativecommons.org/licenses/by-nc-nd/4.0/

\author{
Post-print version of the manuscript published in \\ Ecological Modelling 425, 109030 \\ https://doi.org/10.1016/j.ecolmodel.2020.109030
}

Editorial for

Ecological Modelling Virtual Special Issue

Modelling Forest Ecosystems

\title{
Modelling Forest Ecosystems: a crossroad between scales, techniques and applications
}

\author{
Juan A. Blanco ${ }^{1, *}$, Aitor Ameztegui ${ }^{2,3}$, Francisco Rodríguez ${ }^{4}$
}

Guest Editors

${ }^{1}$ Dep. Ciencias, Universidad Pública de Navarra, Campus de Arrosadía, Pamplona, Navarra, 31013, Spain. juan.blanco@unavarra.es

${ }^{2}$ Dept. Agriculture and Forest Engineering, Universitat de Lleida, Av. Rovira Roure 191, 25198, Lleida, Spain. aitor.ameztegui@udl.cat

${ }^{3}$ Joint Research Unit CTFC-Agrotecnio, Ctra. Sant Llorenç km.2 25280, Solsona, Spain.

${ }^{4}$ EiFAB - iuFOR, Universidad de Valladolid, Soria, 42004, Spain. francisco.rodriguez.puerta@uva.es

"Corresponding author: juan.blanco@unavarra.es

\section{Introduction}

Forests are likely the most complex ecosystems on Earth, as they cross scales from the largest and longestlived organisms on the planet (trees) with a myriad of diminutive organisms such as microarthropods, fungi, or bacteria, to create habitat for thousands of plant and wildlife species around the world. In addition, forests are vital for livelihoods of human populations, providing a multitude of goods and services both in the forest neighborhood as well as in other regions further away. Such socio-ecological complexity has been translated 
into different modelling approaches to try to understand forest systems, from continental, regional or landscape-scales to individual-base models. Similarly, forest models have been developed at all kind of complexity levels, from very complex, integrative models to simpler models focused on one specific ecophysiological process. Thus, continuous efforts by the forest modelling community have provided a wealth of research and expertise, but at the same time have generated a dispersion and lack of linkages between different modelling approaches and applications.

Forest science is integrative by nature: understanding climate, soil and water processes is as important as understanding plant eco-physiology to understand how forests work. Therefore, forest science has evolved during the last centuries to understand how trees and forests grow, and which patterns and processes rule their development through time and space. Following the common scientific method, empirical reductionist approaches tried to isolate and study one ecological factor or variable at a time (Popper 1968), trying to reduce the complexity inherent to ecological processes. On the contrary, theoretical ecological models explore the ecological interactions among the components that exist in a forest, assembling the pieces of evidence generated through traditional field and lab work (Kimmins et al. 2010). In this special issue, we want to show some of the latest developments in forest modelling, understanding forests like working systems in which human intervention has played and is still playing a historical role, and will likely do so in the future.

Following the sharp increase in data availability, modelling is now being applied in forest ecosystems at multiple scales, from continental and regional studies on forests and species distribution to leaf scales modelling plague and pathogen infestation in individual branches. Similarly, models are being applied to understand short-time processes such as nutrient transport in cells, to extremely long scales such as genetic drift in tree populations. From the application point of view, models are also being applied from purely ecological issues, such as coexistence and resource competition among tree species, to multidisciplinary socio-economic-ecological issues, such as design of tourist routes inside natural reserves, estimating timber flow to sawmills under climate change scenarios, or engineering concerns such as designing forest harvesting machinery with lower ecological footprint (in energy, rut formation, noise, etc.).

When organizing this special issue, we (the guest editors) decided to carry out a quick overview of current trends in forest modelling. To do so, we used Clarivate's Web of Science to carry out a search in the top five journals with "Forestry" as their unique category (Forest Ecology and Management, Tree Physiology, Trees - Structure and Function, Canadian Journal of Forest Research, International Journal of Wildland Fire), and two journals specialized in ecological modeling (Environmental Modelling and Software and Ecological Modelling). We searched for papers containing the same keywords as the papers published in the present article collection on modelling forest ecosystems. We limited our search to the last three complete years in the database (2017 and 2019). As several hundred papers were obtained, we made our personal selections as our search was not intended to be exhaustive, only to provide a sense on what is going on nowadays in the forest ecological modelling community (Table 1). 


\section{Theoretical developments: are the classics still valid?}

Although growth and yield tables have been used in forest science for more than 200 years, the model JABOWA by Botkin et al. (1972) is usually considered as the first modern model based on computational algorithms. Since them, algorithm-based forest models have kept evolving, creating an impressive "forest of models" by itself. For example, Blanco et al. (2015) described 200 models for mixed forests alone. Many of such models were created for specific applications, whereas others pretended to be theoretical explanations of how forest ecosystems grow. Some of those models have over time generated a community of users that have kept the models' use and development thriving. We asked ourselves if some of those models, developed in the 1980s and 1990s, were still considered as valid research tools by the forest modelling community. Indeed they are, with several "classical" forest models being actively used.

In Africa, Armstrong et al. (2018) used FORMIND to simulate tropical forests in Madagascar. In Asia, Zhu et al. (2019) simulated Chinese temperate forests with FORSKA, whereas Zheng et al. (2018) simulated Metasequoia plantations in Shanghai's urban forests with FORECAST. Huang et al. (2018) integrated the FSV and F3 models in North American temperate forests. Also for the same type of biome, McKenzie et al. (2019) used LANDIS II and PnET, whereas Meyer et al. (2018) used 3-PG in Canada. In Europe, Ameztegui et al. (2017) linked SORTIE-ND to a hydrologic model to study the effects of combined water and light limitations on growth and mortality of temperate conifer forests. Han et al. (2018) combined phenology observations with BIOME-BGC for European temperate forests. Also in Europe, González de Andrés et al. (2017) simulated competition for nutrient, light and water in mixed conifer-broadleaf forests, whereas in this issue Lo et al. (2019) demonstrated the low impact of increased $\mathrm{CO}_{2}$ availability in the productivity of pine forests. Both works used FORECAST Climate. Also in this special issue, Miquelajauregui et al. (2019) used CBM-CFS3 to estimate carbon pools in boreal forests in North America. Such flurry of activity demonstrates that "classical" models have not being kept static since their origins several decades ago, but they have kept evolving, adding new modules, capabilities and refinements as theoretical and empirical findings have indicated the need for them.

Such continuous use of forest models developed in the last years of the $20^{\text {th }}$ century has by no means altered the production of new models. For example, new theoretical developments are happening in the way to define harvestable areas, such as the use of the hydrological neighborhood, a new concept introduced in this issue by Giménez et al. (2019). Also in this special issue, Gómez-Sanz (2019) explores the applicability of the ecological marginality concept to explain vegetative decline in Aleppo pine stands in Spain. However, many of the new models are mainly focused on the understanding of carbon cycles, biomass and timber volume. Indeed, yield tables were the origin of forest models in the $17^{\text {th }}$ century, and estimating timber production continues to be one of the main modelling objectives of the forest modelling community. Current efforts are being focused now in species underrepresented in the international scientific literature. For example, In Africa, Dury et al. (2018) developed a new model of net primary productivity for African tropical forests while Djomo and Chimi (2017) developed a model of biomass and carbon for tropical forests in Cameroon. In Asia, Van Vinh et al. (2019) have recently developed a biomass and carbon model for 
Vietnamese mangroves whereas in this special issue, Kumar et al. (2019) introduce a model to simulate phenological changes in Himalayan pines. Similarly, Khan et al. (2018) have estimated carbon and biomass in Bangladesh forests. In South America, Piponiot et al. (2018) have created a model to estimate volume and mortality of tropical stands in the French Guyana. Resquin et al. (2018) created a new mortality model for temperate forests in Uruguay. In Europe, a dynamic growth model is introduced in this special issue for sweet chestnut (Prada et al. 2019).

Theoretical developments are steadily moving towards more integrative models. Increasing model complexity by incorporating either more ecological processes or more ecological actors is a clear trend, as new ways are developed to deal with the issues of increasing complexity (Kimmins et al. 2008). Some of such processes are natural disturbances, whose understanding has changed from being considered as "natural disasters" to inherent parts of forest ecosystem functioning. Disturbances are key processes in forest ecosystem dynamics (Oliver and Larson 1996). They strongly influence the structure, composition and functioning of forest ecosystems (Franklin et al. 2002) and determine the spatial and temporal patterns of forested landscapes (Forman 1995). Natural disturbances play a key role in ecosystem dynamics and are important factors that should be taking into account when implementing sustainable forest ecosystem management. Quantitative models are frequently employed to tackle the complexities associated with disturbance processes (Seidl et al. 2011). In short, ecological disturbances (in this editorial we will evaluate them as wind, fires, diseases and pests) are a critical challenge for natural resource managers (Baggio and Hillis 2018). Cannon et al. (2017) showed a review and classification of interactions between forest disturbance from wind and fire.

Snow and wind damages are one of the major abiotic disturbances playing a key role in forest ecosystems, affecting both stand dynamics and forest management decisions. Although the most common empirical approach to develop stand-scale windthrow models has been logistic regressions (Kramer et al. 2001, Mitchell et al. 2001, Rich et al. 2007), new methods from artificial intelligence recently proved to be superior in modelling windthrow susceptibility (Hanewinkel et al. 2004). In this issue, Díaz-Yáñez et al. (2019) analyze the occurrence of wind and snow damage based on data from four consecutive Norwegian National Forest Inventories. Their methodological approach was based on boosted regression trees, a machine learning method also used by Suvanto et al. (2019). Other non-parametric quantitative models such as classification and regression trees or gradient boosting have been commonly used to model windthrow susceptibility (Dobbertin 2002, Lindemann and Baker 2002, Kupfer et al. 2008). Wind-risk simulators such as ForestGALES allow for a good understanding of the dynamics involved in wind damage, and for calculations of risk to be made, and therefore provide vital information on the best practices to minimize such risk. Recently, Locatelli et al. $(2016,2017)$ parameterized ForestGALES for three of the arguably most widespread and commercially important species at global level: Eucalptus globulus, Picea sitchensis and Pinus pinaster.

One of the main consequences of disturbances is tree mortality. As such, fire is always an element to keep in mind in forestry. The prediction of fire propagation across landscapes is necessary for safe and effective fire 
management. Recent developments in fire simulators allow predicting fire spread and behavior in real-time. Forestland managers rely on predictions of tree mortality generated from fire behavior models to identify stands for post-fire salvage and to design fuel reduction treatments that reduce mortality (Barker et al., 2019). In this issue, Cardil et al. (2019) present an innovative method implemented in the Wildfire Analyst and Wildfire analyst pocket (see Monedero et al. 2019, also in this issue), to adjust fire simulations in real time. Cruz et al., (2018) analyzed the predictive accuracy of models currently used operationally in Australia for predicting fire spread rates in five different fuel types compared to their previous counterparts, demonstrating the utility of such models in real-life management.

Fire determines forest ecosystem functioning not only at the time of burning and spreading, but also afterwards. In this issue, Canelles et al. (2019) parameterize a model of post-fire regeneration and species growth, including climate influences on such processes, from the stand to landscape. Similarly, Foster et al. (2019) analyze the importance of tree- and species-level interactions with wildfire, climate, and soils under a warming climate. However, due to the high cost and time to conduct fieldwork, remote sensing is an appealing alternative to assess post-fire condition over larger areas (Klauberg et al. 2019). In this way, Fernández-Guisuraga et al. (2019) demonstrates the potential of fine-grained satellite imagery to conduct post-fire recovery studies with a high degree of generality across different contexts. Past research has relied overwhelmingly on logistic regression analysis that predicts post-fire tree status as a binary outcome. Leuenberger et al. (2018) recently compared two stochastic versus a well-established deterministic methodological approaches for wildfire susceptibility mapping. Grayson et al. (2017) validated 54 logistic regression mortality models from seven published articles and two sets of mortality guidelines from two sources. However, Sherman et al. (2019) demonstrated that random forest algorithms improve discrimination of imbalanced data. In this special issue, Klauberg et al. (2019) characterize fire effects on conifers at tree level from airborne laser scanning and high-resolution, multispectral satellite data, using methods based on artificial intelligence. Savage et al. (2017) used Landsat satellite imagery to map percent canopy cover by species and sub-canopy species counts to be used in adaptive forest management strategies using zeroinflated models. Chen et al. (2017) developed a predictive model for estimating forest surface fuel load in Australian eucalypt forests with LiDAR data. Barker et al. (2019) evaluated post-fire mortality predictions using the Forest Vegetation Simulator Fire and Fuels extension. Finally, Huang et al. (2018) simulated spatiotemporal forest change from field inventory, remote sensing, growth modeling, and management actions.

Forest insects and pathogens have enormous impacts on community dynamics, carbon storage and ecosystem services. However, its modelling is limited due to their variability in severity and extent (Dietze and Matthes 2014). In the context of urban trees, Koch et al. (2018) recently modeled urban distributions of host trees for invasive forest insects using field inventory data. However, studies at stand or landscape level are much more numerous. In this case, remote sensors are also a very common source of information. Liang et al. (2017) integrated cellular automata, remote sensing, and a geographic information system to understand the insect ecological processes and tested it with measured data of mountain pine beetle. Navarro-Cerrillo et al. (2019) assessed holm oak defoliation by classifying two different levels using a combination of multispectral 
WorldView-2 and airborne laser scanning data in an automated random forest modeling approach. Barnes et al. (2017) evaluated metrics from high-density discrete airborne laser scanning point clouds and canopy height models to identify individual trees infected with Phytophthora ramorum and to discriminate between four disease severity categories using a k-nearest neighbor classifier. Smigaj et al. (2019) investigated the use of unmanned aerial vehicle (UAV)-borne thermal systems for detecting disease-induced canopy temperature increase and explores the influence of the imaging time and weather conditions on the detected relationship.

Finally, the use of simulators and the influence of global change is focusing a new framework for analysis. Ikegami and Jenkins (2018) estimate global risks of a forest disease under current and future climates using MaxEnt (a useful tool to predict species occurrence), ARTEMIS (a growth model), and a simple thermal model. In this line, Honkaniemi et al. (2018) evaluate interaction of disturbance agents on Norway spruce based on a mechanistic model of bark beetle dynamics integrated in the simulation framework WINDROT. In this issue, Suárez-Muñoz et al. (2019) simulate the population dynamics of the forest pest Thaumetopoea pityocampa through INSTAR, a new Agent-Based Model.

\section{Technological developments: modelling supported by remote sensing data}

Remote sensing applied to forest management comprises mainly four categories: forest cover classification, estimation of forest attributes, detection of changes in the forest and spatial modeling (Franklin 2001). On the other hand, the importance of remote sensors is based on the fact that LiDAR and satellite imagery are a cost-effective alternative that can provide high-resolution characterizations of variation in forest structure among landform types. As such costs keep coming down and technology becomes quickly available for nonspecialized scientists, remote sensing is quickly gaining popularity in the forest modelling community.

Developing a robust and cost-effective method for accurately estimating forest's carbon pools over large areas is a fundamental requirement for the implementation of Reducing Emissions from Deforestation and forest Degradation (REDD; Phua et al. 2017). The recently launched Sentinel imagery offers a new opportunity for forest mapping and monitoring (Chen et al. 2018). In smaller study areas, Djomo and Chimi (2017) developed allometric equations to estimate aboveground biomass using crown diameter as predictor variable. Although managers and researchers have often been reluctant to use LiDAR for characterizing structure because of low confidence in its capacity to approximate actual tree distributions, Wiggins et al. (2019) show an example of how to use LiDAR to develop high-resolution reference models of forest structure and spatial pattern. Tree crown geometry and height, especially when coupled with remotely sensed data, can aid in the characterization of tree and forest structure (Sullivan et al. 2017). Forest processes that play an essential role in carbon sequestration, such as light use efficiency, photosynthetic capacity, and trace gas exchange are closely tied to the three-dimensional structure of forest canopies. Kamoske et al. (2019) evaluate leaf area density from airborne LiDAR, comparing sensors and resolutions in a temperate broadleaf forest ecosystem. Finally, Mohan et al. (2019) present an airborne-based laser scanning tree detection method applied for automatically identifying individual coconut trees in a plantation in southeast Brazil. 
In addition, the evaluation of accuracy is essential for assuring the reliability of ecological models. Pascual et al. (2019) examined the problem of selecting predictor variables derived from airborne laser scanning when using stepwise and multiple linear regression, and when using kNN imputation using Random Forests to select predictor variables. Moreover Valbuena et al. (2017) concluded that statistical measures of accuracy, precision and agreement are necessary but insufficient for model evaluation. They therefore advocate for incorporating evaluation measures specifically devoted to testing observed-versus-predicted fit, and to assessing the degree of overfitting. Finally, both sophisticated statistical methods and supercomputing tools are increasingly comdined in scientific studies. Li et al. (2019) evaluate a GPU-based lightweight parallel processing toolset for LiDAR data for terrain analysis. Hawrylo et al. (2019) compared the accuracy of multiple linear regression and random forest methods for predicting growing stock volume of Scots pine stands using Sentinel-2 satellite imagery and airborne image-derived point clouds.

\section{Methodological developments: statistics moving into new realms}

Statistical techniques that were once considered advanced are becoming increasingly mainstream in ecological modelling. For example, in this special issue Pavão et al. (2019) demonstrated the differences between using discrete and continuum community models with Bayesian methods in Azorean plant communities. Indeed, machine-learning methods are becoming increasingly used tools in biology and ecology (Cutler et al. 2007). Algorithms such as Random Forests (Breiman 2001) are now widely used for classification and prediction purposes, particularly in the remote sensing field, where they have become a widely accepted procedure (Belgiu and Drăguţ 2016). A random forest is a classification and regression method based on the aggregation of a large number of classification and regression trees. Trees are constructed by drawing a subset of bootstrap training samples from the data, yielding a prediction of the response variable given the values of the predictors (Boulesteix et al., 2012). Random forest algorithms have a number of advantages that have made them so successful, the most crucial being their great predictive capacity, both for classification and regression. As a non-parametric method, random forests do not make distributional assumptions about the response variable, nor the predictors or their relationship, and admit large sets of predictors, even correlated among them. Moreover, they are robust against outliers and capable of imputing missing data values. However, their en masse implementation has come along with the development of software that eases their use (Boulesteix et al. 2012), especially R packages such as randomForest (Liaw and Wiener 2002) or party (Hothorn et al. 2017).

Random forests are ideal for large datasets with a multi-dimensional independent variable space. Therefore, they are often used to relate information from remote sense sources - which are inherently large and multidimensional - to stand-scale forest characteristics, allowing the prediction and spatialization of the latter. For instance, Brubaker et al. (2018) used random forests to spatialize predictions of tree and shrub biomass from LiDAR, whereas Chen et al. (2019) calculated aboveground biomass from SAR data, using random forest krigging to spatialize the predictions. An increasingly promising trend is the combination of several sources of remote sensing information. For example, Navarro-Cerrillo et al. (2019) successfully used random forests to integrate multispectral imagery and aboveground LiDAR to identify trees damaged by Phytophtora, and 
similar approaches have been used to identify the main drivers of fire severity (Garcia-Llamas et al., 2019b; Klauberg et al., 2019). The suitability of random forests for relating remote sensing to field data has been assessed by several authors. Recently, Zhang et al. (2018) compared different distance metrics to integrate MODIS data with forest inventory data in China, and found that RF outperformed the six metrics evaluated. Moreover, Zhao et al. (2019) compared the ability of four machine learning algorithms to estimate a set of forest parameters (age, aboveground biomass, canopy cover, DBH, density, etc.), and observed that random forests yielded the highest determination coefficient $\left(\mathrm{R}^{2}\right)$ and the lowest error (measured as rRMSE) for all the parameters. However, Pascual et al. (2019) observed that random forests are more affected than parametric approaches when there are co-registration errors between remote sensing data sources and ground surveys, and recent studies have warned that spatial cross-validation is essential to prevent overoptimistic model performance when there is spatial autocorrelation (Meyer et al. 2019, Schratz et al. 2019).

Other authors have taken advantage of the flexibility of random forests and the availability of large spatial databases of variables such as climate or soil to infer their role in the distribution of species, leading to a new generation of species distribution models (see Castaño-Santamaria et al. 2019, Gobeyn et al. 2019). Such models can cover areas with scarce field data (Pelletier et al. 2019) or produce spatialized predictions of forest attributes at continental scales (Roxburgh et al. 2019). When compared to other model algorithms for species distribution models, random forests have yielded similar or superior accuracy that well established algorithms such as maximum entropy - MaxEnt (Jarnevich et al. 2017).

The increased availability of large databases such as national forest inventories has led to the increasing use of random forests algorithms to identify the factors driving a particular variable of interest, often associated with forest productivity. For example, Shi et al. (2018) quantified the driving factors of carbon stock in bamboo forests, and Thom and Keeton (2019) identified stand structure as the main driver of carbon storage disparities between different forest types in North America. However, when comparing the predictive performance of various techniques to predict aboveground biomass from field observations, Corona-Nuñez et al. (2017) found that general linear models (GLM) and general additive models (GAM) outperformed more complex approaches, including random forests. In recent years, applications of random forests algorithms in forestry are becoming progressively less restricted than measuring only productivity. Recently, Andrews et al. (2018) and Ma et al. (2019) have used random forests to identify the drivers of self-thinning and maximum stand density index, which can aid forest managers to better predict and manage stand dynamics. Random forest algorithms are currently also extensively used in forest fire research, including the determination of drivers of burn rate (Boulanger et al. 2018), fire severity (Garcia-Llamas et al. 2019a, 2019b, Klauberg et al. 2019) or burnt area (Ying et al. 2018). Other uses include assessing drivers of crown defoliation (Iacopetti et al. 2019, Navarro-Cerrillo et al. 2019), phosphorus concentrations in trees (Faeth et al. 2019), and seedling survival (Dyderski and Jagodzinski 2019, Kupferschmid et al. 2019), predicting understory vegetation structure (Krebs et al. 2019), or estimating bird abundance and diversity (Reise et al. 2019), among others. 
In all these cases, the method is used with explanatory rather than predictive purposes. In this sense, most studies use the capacity of random forests to classify and rank the variables according to their importance as predictors, using variable importance measures (VIMs). In addition, the ability of random forests algorithms to deal with any type of variable, without making assumptions about its distribution or potential correlations between variables, is commonly cited by the authors as one of the reasons for choosing this technique. This often leads to approaches where numerous predictors - often non-independent one from another - are introduced into the models, without careful consideration of the ecological sense of such predictors or the consequences for the model performance. In this regard, although correlation between predictors does not usually have much influence on prediction accuracy, variable importance measures can be strongly affected (Boulesteix et al. 2012), leading to biases in variable selection (uninformative predictors can be often preferred over informative ones if they are highly correlated with some of the other predictors). In case of highly dimensional predictor spaces, it might thus be useful to incorporate a variable selection procedure to better separate noise from informative predictors (Boulesteix et al. 2012). This can also help to detect causal relationships that allow for improved inference about how the ecosystems actually functions.

\section{Where the wild trees are ... where the wild trees will be?}

Understanding distribution of organisms is at the origin of ecology, a scientific discipline that arguably started mostly focused on biogeography. As an example, one of the earliest models is the beautiful painting by Alexander Humboldt in 1802 depicting vegetation distribution on the slopes of the Chimborazo (the highest peak in Ecuador). Nowadays, species distribution models - also called habitat models, niche-based models, habitat suitability models or climate envelope models - relate species occurrence data to environmental variables, generating maps that predict past, present or future species distribution (Pecchi et al. 2019). This approach was developed in the 1980s, and was initially based on the concept of ecological niche derived by Hutchinson (1957), later refined by several authors. The method was firstly limited by the availability of sufficient reliable climatic data at large spatial scales, and the release of global climatic datasets thus meant a golden era of species distribution models in the late 1990s and early 2000s. After facing important criticism for not considering issues such as biotic competence or species adaptive capacity (Lo et al. 2010), species distribution models have been able to cope with these limitations (Guisan and Thuiller 2005), and are now recognized as a powerful method to forecast the most likely impact of a changing climate on the geographic distribution of species (Booth 2018, Pecchi et al. 2019).

The use of species distribution models in modeling forest ecosystems has continued to grow, as shown by the ever increasing number of papers published between 2000 and 2019 (Pecchi et al. 2019). Traditionally, this modelling approach has mostly focused on species with particular interest such as those with high economic value (Pelletier et al. 2019), or with importance for wildlife and biodiversity (Shirk et al. 2018). However, they are particularly interesting for invasive, rare or endangered species (Arieira et al. 2018, Srivastava et al. 2018, Thurm et al. 2018). Species distribution models have allowed a more precise definition of the thermal niche of endangered species (Koo et al. 2017a), which is fundamental for identifying future areas that can act as thermal microrefugia in the event of climate change. Li et al. (2018) and Liang et al. (2018) observed that 
some species conserve their native climatic niche when they expand into new areas, which suggests that distribution models based on the native area of a species could be used to assess suitable habitat for introduction or to identify areas with high risk of encroachment (Liang et al. 2018, Song et al. 2019). Others have specifically focused on modeling the regeneration niche of species (Gill et al. 2017, Soto et al. 2019), which provides important insights for designing restoration practices or assessing invasion risk under future climate and disturbance regimes.

In the last few years, species distribution models have been used extensively to explain the influence of bioclimatic variables on plant pathogen or pest distribution. For instance, (Bosso et al. 2017) characterized the geographical distribution of the fungus Diplodia sapinea, and projected that the range where disease can outbreak will expand in response to the increase in temperatures. Similarly, after defining the ecological niche of the pine wood nematode (Bursaphelenchus xylophilus), Ikegami and Jenkins (2018) reported that susceptible host species that are currently outside the area suitable for the development of the nematode may become susceptible in large parts of their range. Several authors have assessed the environmental variables that explain the distribution of the pathogen Phytophthora cinnamomi, involved in the general oak decline that affects large parts of Mediterranean oaks in the Iberian Peninsula (Duque-Lazo et al. 2018, HernándezLambrano et al. 2019, 2018), but also those of the beetles that can act as vectors of the pathogen (DuqueLazo and Navarro-Cerrillo 2017). After obtaining accurate predictions for the current potential distribution of the pathogen, Hernandez-Lambrano et al. (2018) forecasted potential further expansion along the northeast and southeast Spain and central Portugal. In this regard, assessing the climatic suitability of both host tree and the insect populations has been revealed as a promising method to anticipate tree mortality episodes driven by pests and pathogens, particularly under increasingly frequent extreme climatic events (Jaime et al. 2019).

The use of species distribution models is not yet free of methodological challenges. The takeoff of this type of models occurred as spatial databases of species distribution and environmental factors with global reach became readily available, and has continued ever since, incorporating new data sources from remote sensing (Jose-Silva et al. 2018, Pecchi et al. 2019). In this issue, Ruiz-Benito et al. (2020) provide an extensive review on the data sources available to model the impacts of climate change on forest ecosystems. Global databases on species presence such as GBIF are fundamental sources of information for species distribution models. However, they require careful monitoring to detect cases to be eliminated (due to wrong species identification or positioning), and also do not provide absence data. Given that the method to generate background or pseudo-absence locations affects model outcomes (Jarnevich et al. 2017, Liang et al. 2018), some authors prefer to work with data from forest inventories, which usually include real absence data (Booth 2018). In this regard, Mateo et al. (2018) showed that opportunistic, low-cost sampling strategies can provide similar accuracy than systematic sampling campaigns.

Nevertheless, the main limit for the development of species distribution models was, for a long time, the availability of reliable climatic data at large spatial scales, so the publication of WorldClim (Hijmans et al. 2005) represented a cornerstone in their development, to the extent that it has become a standard in the 
discipline (Booth 2018). Availability of global soil data has lagged behind that of climatic data, but the situation has significantly improved with the release of the SoilGrids250m database (Hengl et al. 2017). However, some recent studies show that these global databases can lack an adequate coverage in some regions of the globe, producing misleading projections, especially in topographically complex regions (Bobrowski and Schickhoff 2017, Marchi et al. 2019). In the same line, Moudry et al. (2018) observed that using global digital elevation models led to lower predictive capacity of the species distribution models due to vertical bias, and argue for the use of local, high-accuracy digital elevation models (DEMs) when possible.

Species distribution models still have room to grow. In recent years, a myriad of algorithms has been developed for the elaboration of this type of models, either regression-based (generalized linear models, generalized additive models, multivariate adaptive regression spline - MARS) or based on machine learning (artificial neural networks - ANN, classification and regression trees - CART, random forests - RF), (see Pecchi et al. 2019, for an in-depth review). In particular, random forest are gaining currency due to their higher predictive capacity and their flexibility (see previous section). Nevertheless, the maximum entropy approach (MaxEnt) continues to dominate, and still represents almost $90 \%$ of the work with species distribution models. However, approaches based on ensembles of models (i.e. the combination of predictions from different algorithms) have gained ground in the last years. In general, this approach seems to improve the predictive capacity of species distribution models and reduces the uncertainty associated with them (Koo et al. 2017b), so its use is expected to become more widespread. Other studies aim at minding the gap between global approaches (at coarse spatial resolutions) and species distribution models built at landscape scales. Promising approaches in this line include the use of "hierarchical niche models" (Mateo et al. 2019), evolutionary algorithms (Gobeyn et al. 2019), or the use of Bayesian meta-modelling frameworks to integrate correlative species distribution models with physiological models (Talluto et al. 2016).

\section{Bringing down the barriers between scales: still a challenge?}

Traditionally, choosing the scale at which a model will work has been one of the very first steps in developing a forest model (Kimmins et al. 2010). In fact, the scale (time, space and biological level) at which a model will operate defines both the modelling approach and the application of such a model (Blanco 2013). However, it has also been recognized that for each given scale, any ecological process in a forest is influenced by other processes happening at smaller or bigger time, spatial and biological scales (Urban 2005). With the increasing availability of detailed data at regional, continental and even global scales, modelling forests at regional or continental scales is becoming more feasible. This trend is also pushed by the acknowledgement that some of the most pressing issues in forest ecology occur at regional to continental, such as climate change, pollution or land use change, among others (Bonan and Doney 2018).

As a direct consequence of such global issues, it is remarkable that one of the main drivers for regional modelling exercises, particularly in regions where data is scarce for many species, is still the estimation of biomass (and therefore carbon pools) stored in forests. This is usually done with empirical models such as allometric equations, which relate tree size attributes with volume, transforming it then in biomass with 
different factors. In North America, this approach has been applied by Affleck (2019), in NW USA`s forests. In Europe, this approach has been followed by Correia et al. (2018) in Mediterranean pine forests, and by Forrester et al. (2017) in temperate forests. In Africa, some of the latest representatives of this type of modelling are Fayolle et al. (2018) in forests of the Congo River basin, Van der Vyven and Cowling (2019) for African tropical forests, or Mensah et al. (2018) in temperature South African forests. In Asia, Fu et al. (2017) have also followed this approach.

However, not only carbon is interesting for forest modelers, and other regional issues such as fire spread are also important drivers for modelling. In this sense, Cardil et al. (2019b) have developed models to estimate the effects of fire suppression in Quebec (eastern Canada), Clements et al. (2019) have studied fire spread rates in Texas (SW USA), Ruffaut and Mouillot (2017) in SE France and Molina et al. (2019) in southern Spain. Another issue that has attracted the attention of forest modelers working at regional to continental scales has been regeneration processes. Indeed, Kralicek et al. (2018) has estimated seedling regeneration in temperate forests of NW USA, Krebs et al. (2017) has modelled cone production by conifers in the Yukon (NW Canada), Mathys et al. (2018) have compared seedling and mature tree distributions in British Columbia (western Canada) and Talucci et al. (2019) have recruitment drives also for British Columbia. In other regions, Vergarechea et al. (2019) have studied regeneration rates for pine species in Spain.

Judging from what most of the forest modelers working at regional to continental scales seem to be doing in the last few years, the most suitable approach is the development of new empirical models based on large databases. This is so even if the linkage of process-based stand-level models with empirical regional-scale models has been done for several years (see the review by Lo et al. 2015). This research line is still alive, as there have been lately several successful attempts to link stand-level forest models with regional to continental simulators to upscale the outcomes of process-based models. Recent good examples are the work by Attia et al. (2019) using the G'Day model with inventories to estimate carbon and water flows in Eucalyptus plantations in Brazil, the linkage of the gap model SIBBORK with regional databases by Brazhsnik and Shugart (2017) to simulate size attributes of forests in Siberia, the regional-level calibration of the 3-PG model by Xie et al. (2017) for Larix forests in NE China, or the combination of the models FullCAN, 3-PG and TYF by Roxbugh et al. (2019) for Australian forests. Hence, the coexistence of empirical and process-based models seems to keep being fruitful to develop better understanding of ecological process in forests at multiple scales, although no doubt that there is always room for further work.

\section{Conclusions: a bright way ahead}

As Guest Editors of the present special issue on Modelling Forest Ecosystems, and also organizers of a session on forest modelling at the $22^{\text {nd }}$ biennial conference of The International Society for Ecological Modelling (ISEM) held in Salzburg (Austria) on October $4^{\text {th }}, 2019$, we have been very pleased by the number and quality of the contributions submitted, particularly leaded by young researchers. Different approaches have been gathered in this special issue showing both traditional and groundbreaking ways to simulate ecological processes in forest ecosystems at multiple scales, and dealing not only with trees, but 
also with all the other components of forest communities. Indeed, a bright way lays ahead for those who want to explore new technologies to acquire data, new techniques to process data, new ideas on how represent ecological processes in forests, or how to link such processes through scales. We hope that the authors and readers of this special issue have enjoyed and learned about forest models as much as the editors have.

\section{The Guest Editors}

Juan A. Blanco

Aitor Ameztegui

Francisco Rodríguez

\section{References}

Affleck, D.L.R. 2019. Aboveground biomass equations for the predominant conifer species of the Inland Northwest USA. Forest Ecology and Management 432, 179-188.

Ameztegui, A., Cabon, A., De Cáceres, M., Coll, L. 2017. Managing stand density to enhance the adaptability of Scots pine stands to climate change: a modelling approach. Ecological Modelling 356, 141-150.

Andrews, C., Weiskittel, A., D’Amato, A.W., Simons-Legaard, E., 2018. Variation in the maximum stand density index and its linkage to climate in mixed species forests of the North American Acadian Region. For. Ecol. Manag. 417, 90-102.

Arieira, J., Padovani, C.R., Schuchmann, K.-L., Landeiro, V.L., Santos, S.A., 2018. Modeling climatic and hydrological suitability for an encroaching tree species in a Neotropical flooded savanna. For. Ecol. Manag. 429, 244-255.

Armstrong, A., Fischer, R., Huth, A., Shugart, H., Fatoyinbo, T. 2018. Simulating forest dynamics of lowland rainforest in Eastern Madagascar. Forests 9, 214.

Attia, A., et al. 2019. Modelling carbon and water balance of Eucalyptus plantation sat regional scale: effect of climate, soil and genotypes. Forest Ecology and Management 449, 117460.

Baggio, J. A., Hillis, V. 2018. Managing ecological disturbances: Learning and the structure of socialecological networks. Environmental Modelling \& Software, 109, 32-40.

Barker, J.S. Fried, J.S. Gray, A.N. Evaluating Model Predictions of Fire Induced Tree Mortality Using Wildfire-Affected Forest Inventory Measurements. 2019, Forests 10, 958.

Barnes, C., Balzter, H., Barrett, K., Eddy, J., Milner, S., Suárez, J.C., 2017. Airborne laser scanning and tree crown fragmentation metrics for the assessment of Phytophthora ramorum infected larch forest stands. For. Ecol. Manage. 404, 294-305.

Belgiu, M., Drăguţ, L., 2016. Random forest in remote sensing: A review of applications and future directions. ISPRS J. Photogramm. Remote Sens. 114, 24-31.

Blanco J.A. 2013. Modelos ecológicos: descripción, explicación y predicción. Ecosistemas 22(3), 1-5

Blanco J.A., González de Andrés E., San Emeterio L., Lo Y.H. 2015. Modelling mixed forest stands: methodological challenges and approaches. In Lek S., Park Y.S., Baehr C., Jorgensen S.E. (Eds.) 
Advanced Modelling Techniques Studying Global Changes in Environmental Sciences. Elsevier, Amsterdam, The Netherlands. Pp 187-213

Bobrowski, M., Schickhoff, U., 2017. Why input matters: selection of climate data sets for modelling the potential distribution of a treeline species in the Himalayan region. Ecol. Model. 359, 92-102.

Bohn, F.J., Frank, K., Huth, A. (2014). Of climate and its resulting tree growth: Simulating the productivity of temperate forests. Ecological Modelling, 278: 9-17.

Bonan, G.B., Doney, S.C. 2018. Climate, ecosystems, and planetary futures: the challenge to predict life in Earth system models. Science 359, 533.

Booth, T.H., 2018. Species distribution modelling tools and databases to assist managing forests under climate change. For. Ecol. Manag. 430, 196-203.

Bosso, L., Luchi, N., Maresi, G., Cristinzio, G., Smeraldo, S., Russo, D., 2017. Predicting current and future disease outbreaks of Diplodia sapinea shoot blight in Italy: species distribution models as a tool for forest management planning. For. Ecol. Manag. 400, 655-664.

Botkin, D. B., Janak, J. F., and Wallis, J. R.: 1972 'Some Ecological Consequences of a Computer Model of Forest Growth', J. Ecol. 60, 849-872.

Boulanger, Y., Parisien, M.-A., Wang, X., 2018. Model-specification uncertainty in future area burned by wildfires in Canada. Int. J. Wildland Fire 27, 164-175.

Boulesteix, A.L., Janitza, S., Kruppa, J., König, I., 2012. Overview of random forest methodology and practical guidance with emphasis on computational biology and bioinformatics. Wiley Interdiscip. Rev. Data Min. Knowl. Discov. 2.

Brazhnik, K., Shugart, H.H. 2017. Model sensitivity to spatial resolution and explicit light representation for simulation of boreal forests in complex terrain. Ecological Modelling, 252, 90-107.

Breiman, L., 2001. Random forests. Mach. Learn. 45, 5-32.

Brubaker, K.M., Johnson, Q.K., Kaye, M.W., 2018. Spatial patterns of tree and shrub biomass in a deciduous forest using leaf-off and leaf-on lidar. Can. J. For. Res. 48, 1020-1033.

Canelles, Q., Aquilué, N., Duane, A., Brotons, L1. 2019. From stand to landscape: modelling post-fire regeneration and species growth. Ecological Modelling. 10.1016

Cannon, J.B., Peterson, C.J., O’Brien, J.J., Brewer, J.S., 2017. A review and classification of interactions between forest disturbance from wind and fire. For. Ecol. Manage. 406, 381-390.

Cardil, A. Monedero, S. Silva, C.A. Ramirez, J. Adjusting the rate of spread of fire simulations in real-time. 2019, Ecological Modelling, 395:39-44.

Cardil, A., Lorente, M., Boucher, D., Boucher, J. Gauthier, S. 2019b. Factors influencing fire supression success in the province of Quebec (Canada). Canadian Journal of Forest Research, 49, 531-542.

Castaño-Santamaria, J., Lopez-Sanchez, C.A., Ramon Obeso, J., Barrio-Anta, M., 2019. Modelling and mapping beech forest distribution and site productivity under different climate change scenarios in the Cantabrian Range (North-western Spain). For. Ecol. Manag. 450, 117488.

Chen, L. Ren, C.Y. Zhang, B. Wang, Z.M., Xi, Y.B. 2018. Estimation of forest above-ground biomass by geographically weighted regression and machine learning with Sentinel imagery. Forests 9, 582. 
Chen, L., Wang, Y., Ren, C., Zhang, B., Wang, Z., 2019. Assessment of multi-wavelength SAR and multispectral instrument data for forest aboveground biomass mapping using random forest kriging. For. Ecol. Manag. 447, 12-25.

Chen, Y., Zhu, X., Yebra, M., Harris, S., Tapper, N. 2017. Development of a predictive model for estimating forest surface fuel load in australian eucalypt forests with LiDAR data. Environmental Modelling and Software, 97, 61-71.

Clements, et al. 2019. The FireFLux II experiment: a model-guided field experiment to improve understanding of fire-atmosphere interactions and fire spread. International Journal of Wildland Fire 28, 308-326.

Corona-Nuñez, R.O., Mendoza-Ponce, A., Lopez-Martinez, R., 2017. Model selection changes the spatial heterogeneity and total potential carbon in a tropical dry forest. For. Ecol. Manag. 405, 69-80.

Correia, A.C., Faias, S.P., Ruiz-Peinado, R., Chianucci, F., Cutini, A., Fontes, L., Manetti, M.C., Montero, G., Soares, P., Tomé, M. 2018. Generalized biomass equations for Stone pine (Pinus pinea L.) across the Mediterranean basin. Forest Ecology and Management, 429. 425-436.

Cutler, D.R., Edwards, T.C., Beard, K.H., Cutler, A., Hess, K.T., Gibson, J., Lawler, J.J., 2007. Random Forests for Classification in Ecology. Ecology 88, 2783-2792.

Cruz, M.G., Alexander, M.E., Sullivan, A.L., Gould, J.S., Kilinc, M. 2018. Assessing improvements in models used to operationally predict wildland fire rate of spread. Environ. Model. Softw. 105, 54-63

Díaz-Yáñez, O., Mola-Yudego, B., Gonzalez-Olabarria, J.R. 2019. Modelling damage occurrence by snow and wind in forest ecosystems. Ecological Modelling. 408. 108741. 10.1016

Dietze, M. C., Matthes, J. H. 2014. A general ecophysiological framework for modelling the impact of pests and pathogens on forest ecosystems. Ecology Letters, 17( 11), 1418-1426.

Djomo, A.N. Chimi, C.D. 2017. Tree allometric equations for estimation of above, below and total biomass in a tropical moist forest: Case study with application to remote sensing. For. Ecol. Manag. 391, $184-193$.

Dobbertin, M., 2002. Influence of stand structure and site factors on wind damage comparing the storms Vivian and Lothar. For. Snow Landsc. Res. 77, 187-205.

Duque-Lazo, J., Maria Navarro-Cerrillo, R., van Gils, H., Groen, T.A., 2018. Forecasting oak decline caused by Phytophthora cinnamomi in Andalusia: Identification of priority areas for intervention. For. Ecol. Manag. 417, 122-136.

Duque-Lazo, J., Navarro-Cerrillo, R.M., 2017. What to save, the host or the pest? The spatial distribution of xylophage insects within the Mediterranean oak woodlands of Southwestern Spain. For. Ecol. Manag. 392, 90-104.

Dury, M., Mertens, L., Fayolle, A., Verbeeck, H., Hambuckers, A., François, L. 2018. Refining species traits in a dynamic vegetation model to project the impacts of lcimate change on tropical trees in Central Africa. Forests 9, 722.

Dyderski, M.K., Jagodzinski, A.M., 2019. Seedling survival of Prunus serotina Ehrh., Quercus rubra L. and Robinia pseudoacacia L. in temperate forests of Western Poland. For. Ecol. Manag. 450, 117498.

Faeth, J., Kohlpaintner, M., Blum, U., Goettlein, A., Mellert, K.H., 2019. Assessing phosphorus nutrition of the main European tree species by simple soil extraction methods. For. Ecol. Manag. 432, 895-901. 
Falloye, A. et al. 2018. A regional allometry for the Congo basin forest based on the largest ever destructive sampling. Forest Ecology and Management, 430, 228-241.

Fernández-Guisuraga, J.M., Calvo, L., Fernández-García, V., Marcos-Porras, E., Taboada, A., Suárez-

Seoane, S., 2019. Efficiency of remote sensing tools for post-fire management along a climatic gradient. For. Ecol. Manage. 433, 553-562.

Forman, R.T.T. 1995. Some general principles of landscape and regional ecology. Landscape Ecology 10, $133-142$.

Forrester, D.I., Tachauer, I.H.H., Annighoefer, P., Barbeito, I., Pretzsch, H., Ruiz-Peinado, R., Stark, H., Vacchiano, G., Zlatanov, T., Chakraborty, T., Saha, S., Sileshi, G.W. 2017. Generalized biomass and leaf area allometric equations for European tree species incorporating stand structure, tree age, and climate. Forest Ecology and Management, 396, 160, 175.

Foster, A., Armstrong, A., Shuman, J., Shugart, H., Rogers, B., Mack, M., Goetz, S., Ranson, J. 2019. Importance of tree- and species-level interactions with wildfire, climate, and soils in interior Alaska: Implications for forest change under a warming climate. Ecological Modelling. 409. 108765. 10.1016

Franklin, S.E., 2001. Remote Sensing for Sustainable Forest Management, Lewis Publishers, Boca Raton, FL, 407 pp.

Frankinl, J.F., Spies, T.A., Van Pelt, R., Carey, A.B., Thornburgh, D.A., Berg, D.R., Lindenmayer, D.B., Harmon, M.E., Keeton, W.S., Shaw, D.C., Bible, K., Chen, J. 2002. Disturbances and sructural development of natural forest ecosystems with silvicultural implications, using Douglas-fir forests as an example. Forest Ecology and Management 155, 399-423.

Fu, Y., Lei, Y., Zeng, W., Hao, R., Zhang, G., Zhong, Q., Xu, M. 2017. Uncertainty assessment in aboveground biomass estimation at the regional scale using a new method considering both smapling error and model error. Canadian Journal of Forest Research, 47, 1095-1103.

Garcia-Llamas, P., Suarez-Seoane, S., Taboada, A., Fernandez-Garcia, V., Fernandez-Guisuraga, J.M., Fernandez-Manso, A., Quintano, C., Marcos, E., Calvo, L., 2019a. Assessment of the influence of biophysical properties related to fuel conditions on fire severity using remote sensing techniques: a case study on a large fire in NW Spain. Int. J. Wildland Fire 28, 512-520.

Garcia-Llamas, P., Suarez-Seoane, S., Taboada, A., Fernandez-Manso, A., Quintano, C., Fernandez-Garcia, V., Manuel Fernandez-Guisuraga, J., Marcos, E., Calvo, L., 2019b. Environmental drivers of fire severity in extreme fire events that affect Mediterranean pine forest ecosystems. For. Ecol. Manag. 433, 24-32.

Gill, N.S., Sangermano, F., Buma, B., Kulakowski, D., 2017. Populus tremuloides seedling establishment: An underexplored vector for forest type conversion after multiple disturbances. For. Ecol. Manag. 404, $156-164$.

Gimenez, J.A., Díaz-Balteiro, L., Bartomeu, M. 2019. The effective hydrological neighborhood: a new concept to formulate harvest area constrains. Ecological Modelling 404, 83-90.

Gobeyn, S., Mouton, A.M., Cord, A.F., Kaim, A., Volk, M., Goethals, P.L.M., 2019. Evolutionary algorithms for species distribution modelling: A review in the context of machine learning. Ecol. Model. 392, 179-195.

Gómez-Sanz, V. 2019. Site-scale ecological marginality; evaluation model and application to a case study. Ecological Modelling 408. 108739 
González de Andrés E., Seely B., Blanco J.A., Imbert J.B., Lo Y.H., Castillo F.J. 2017. Increased complementarity in water-limited environments in Scots pine and European beech mixtures under climate change. Ecohydrology 10, e1810

Grayson, LM., Progar, RA., Hood, SM. 2017. Predicting post-fire tree mortality for 14 conifers in the Pacific Northwest, USA: Model evaluation, development, and thresholds. Forest Ecology and Management 399, 213-226.

Guisan, A., Thuiller, W., 2005. Predicting species distribution: offering more than simple habitat models. Ecol. Lett. 8, 993-1009.

Han, Q., Wang, T., Jiang, Y., Fischer, R., Li, C. 2018. Phenological variation decreased carbon uptake in European forests during 1999-2013. Forest Ecology and Management 427, 45-51.

Hanewinkel, M., Zhou, W., Schill, C., 2004. A neural network approach to identify forest stands susceptible to wind damage. For. Ecol. Manage. 196, 227-243.

Hawrylo, P., Wezyk, P,. 2018. Predicting growing stock volume of scots pine stands using Sentinel-2 satellite imagery and airborne image-derived point clouds. Forests 9, 274.

Honkaniemi J., Ojansuu R., Kasanen R., Heliovaara K. 2018. Interaction of disturbance agents on Norway spruce: a mechanistic model of bark beetle dynamics integrated in simulation framework WINDROT. Ecological Modelling 388: 45-60.

Huang, S. Ramirez, C. McElhaney, M. Evans, K. 2018. Simulating spatiotemporal forest change from field inventory, remote sensing, growth modeling, and management actions. For. Ecol. Manag. 415, 26-37.

Hengl, T., Jesus, J.M. de, Heuvelink, G.B.M., Gonzalez, M.R., Kilibarda, M., Blagotić, A., Shangguan, W., Wright, M.N., Geng, X., Bauer-Marschallinger, B., Guevara, M.A., Vargas, R., MacMillan, R.A., Batjes, N.H., Leenaars, J.G.B., Ribeiro, E., Wheeler, I., Mantel, S., Kempen, B., 2017. SoilGrids250m: Global gridded soil information based on machine learning. PLOS ONE 12, e0169748.

Hernandez-Lambrano, R.E., Gonzalez-Moreno, P., Angel Sanchez-Agudo, J., 2018. Environmental factors associated with the spatial distribution of invasive plant pathogens in the Iberian Peninsula: The case of Phytophthora cinnamomi Rands. For. Ecol. Manag. 419, 101-109.

Hernandez-Lambrano, R.E., Rodriguez de la Cruz, D., Angel Sanchez-Agudo, J., 2019. Spatial oak decline models to inform conservation planning in the Central-Western Iberian Peninsula. For. Ecol. Manag. 441, $115-126$.

Hijmans, R.J., Cameron, S.E., Parra, J.L., Jones, P.G., Jarvis, A., 2005. Very high resolution interpolated climate surfaces for global land areas. Int. J. Climatol. 25, 1965-1978.

Hothorn, T., Hornik, K., Strobl, C., Zeileis, A., 2017. Party: a laboratory for recursive partytioning, R package.

Huang, S., Ramirez, C., mcElhaney, M., Evans, K. 2018. F3: simulating spatiotemporal forest change from field inventory, remote sensing, growth modeling, and management actions. Foest Ecology and Management 415-416, 26-37.

Hutchinson, G.E., 1957. Concluding remarks. Cold Spring Harb. Symp. Quant. Biol. 22, 415-457. Iacopetti, G., Bussotti, F., Selvi, F., Maggino, F., Pollastrini, M., 2019. Forest ecological heterogeneity determines contrasting relationships between crown defoliation and tree diversity. For. Ecol. Manag. 448, $321-329$. 
Ikegami, M., Jenkins, T.A.R., 2018. Estimate global risks of a forest disease under current and future climates using species distribution model and simple thermal model Pine Wilt disease as a model case. For. Ecol. Manag. 409, 343-352. https://doi.org/10.1016/j.foreco.2017.11.005

Jaime, L., Batllori, E., Margalef-Marrase, J., Perez Navarro, M.A., Lloret, F., 2019. Scots pine (Pinus sylvestris L.) mortality is explained by the climatic suitability of both host tree and bark beetle populations. For. Ecol. Manag. 448, 119-129.

Jarnevich, C.S., Talbert, M., Morisette, J., Aldridge, C., Brown, C.S., Kumar, S., Manier, D., Talbert, C., Holcombe, T., 2017. Minimizing effects of methodological decisions on interpretation and prediction in species distribution studies: An example with background selection. Ecol. Model. 363, 48-56.

Jose-Silva, L., dos Santos, R.C., de Lima, B.M., Lima, M., de Oliveira-Junior, J.F., Teodoro, P.E., Eisenlohr, P., da Silva Junior, C.A., 2018. Improving the validation of ecological niche models with remote sensing analysis. Ecol. Model. 380, 22-30.

Khan, M., N., I. Shil, M.C., Azad, M.S., Sadath, M.N., Feroz, S.M., Mollivk, A.S. 2018. Allometric relationships of stem volume and stand level carbon stocks at varying stand density in Swietenia macrophylla King plantations, Bangladesh. Forest Ecology and Management 430, 639-648.

Kamoske, A.G., Dahlin, K.M., Stark, S.C., Serbin, S.P. 2019. Leaf area density from airborne LiDAR: Comparing sensors and resolutions in a temperate broadleaf forest ecosystem. For. Ecol. Manag. 433, 364-375.

Kimmins J.P., Blanco J.A., Seely B., Welham C., Scoullar K. 2008. Complexity in Modeling Forest Ecosystems; How Much is Enough? Forest Ecology and Management, 256(10), 1646-1658.

Kimmins J.P., Blanco J.A., Seely B., Welham C., Scoullar K. 2010. Forecasting Forest Futures: A Hybrid Modelling Approach to the Assessment of Sustainability of Forest Ecosystems and their Values. Earthscan Ltd. London, UK. 281 pp.

Klauberg, C., Hudak, A.T., Silva, C.A., Lewis, S.A., Robichaud, P.R., Jain, T.B., 2019. Characterizing fire effects on conifers at tree level from airborne laser scanning and high-resolution, multispectral satellite data. Ecol. Model. 412, 108820.

Koch, FH., Ambrose, MJ., Yemshanov, D., Wiseman, PE., Cowett, FD. 2018. Modeling urban distributions of host trees for invasive forest insects in the eastern and central USA: A three-step approach using field inventory data. Forest Ecology and Management 417: 222-236.

Koo, K.A., Kong, W.-S., Park, S.U., Lee, J.H., Kim, J., Jung, H., 2017a. Sensitivity of Korean fir (Abies koreana Wils.), a threatened climate relict species, to increasing temperature at an island subalpine area. Ecol. Model. 353, 5-16.

Koo, K.A., Park, S.U., Kong, W.-S., Hong, S., Jang, I., Seo, C., 2017b. Potential climate change effects on tree distributions in the Korean Peninsula: Understanding model \& climate uncertainties. Ecol. Model. $353,17-27$.

Kralicek, K., sánchez Meador, A.J., Rathbun, L. 2018. Development and assessment of regeneration imputaiton models for National Forests of Oregon and Washington. Forest Ecology and Management 409 667-682.

Kramer, M.G., Hansen, A.J., Taper, M.L., Kissinger, E.J., 2001. Abiotic controls on long- term windthrow disturbance and temperate rain forest dynamics in southeast Alaska. Ecology 82, 2749-2768. 
Krebs, M.A., Reeves, M.C., Baggett, L.S., 2019. Predicting understory vegetation structure in selected western forests of the United States using FIA inventory data. For. Ecol. Manag. 448, 509-527.

Krebs, C.J., O`Donoghue, M., Taylor, S., Kenney, A.J., Hofer, E.J., Boutin, S. 2017. Predicting white spruce cone crops in the boreal forests of southern and central Yukon. Canadian Journal of Forest Research 47, 47-32.

Kuma, M., Kalra, N., Khaifer, P., Ravindranath, N.H., Singh, V., Singh, H., Sharma, S., Rahamayan, S. 2019. PhenoPine: a simulation model to trace the phenological changes in Pinus roxhburghii in response to ambient temperature rise. Ecological Modelling 404, 12-20.

Kupfer, J.A., Myers, A.T., McLane, S.E., Melton, G., 2008. Patterns of forest damage in a southern Mississippi landscape caused by hurricane Katrina. Ecosystems 11, 45-60.

Kupferschmid, A.D., Buetikofer, L., Hothorn, T., Schwyzer, A., Brang, P., 2019. Quantifying the relative influence of terminal shoot browsing by ungulates on tree regeneration. For. Ecol. Manag. 446, 331-344.

Leuenberger, M., Parente, J., Tonini, M., Pereira, M. G., and Kanevski, M. 2018. Wildfire susceptibility mapping: deterministic vs. stochastic approaches. Environ. Model. Softw. 101, 194-203.

Li, G., Zhang, X., Huang, J., Wen, Z., Du, S., 2018. Afforestation and climatic niche dynamics of black locust (Robinia pseudoacacia). For. Ecol. Manag. 407, 184-190.

Li J., Xu Y., Macrander H., Atkinson L., Thomas T., Lopez M., 2019. GPU-based lightweight parallel processing toolset for LiDAR data for terrain analysis. Environmental Modeling and Software. 117: 5568.

Liang, L., Li, X., Huang, Y., Qin, Y., Huang, H., 2017. Integrating remote sensing, gis and dynamic models for landscape-level simulation of forest insect disturbance. Ecol. Model. 354, 1-10.

Liang, W., Papes, M., Tran, L., Grant, J., Washington-Allen, R., Stewart, S., Wiggins, G., 2018. The effect of pseudo-absence selection method on transferability of species distribution models in the context of non-adaptive niche shift. Ecol. Model. 388, 1-9.

Liaw, A., Wiener, M., 2002. Classification and Regression by randomForest. R News 2, 18-22.

Lindemann, J.D., Baker, W.L., 2002. Using GIS to analyse a severe forest blowdown in the Southern Rocky Mountains. Int. J. Geograph. Inform. Sci. 16, 377-399.

Lo Y.H., Blanco J.A., Kimmins J.P. 2010a. A word of caution when projecting future shifts of tree species ranges. The Forestry Chronicle, 86(3), 312-316.

Lo Y.H., Blanco J.A., Welham C., Wang M. 2015. Maintaining Ecosystem Function by Restoring Forest Biodiversity: Reviewing Decision-Support Tools that link Biology, Hydrology and Geochemistry. In: Lo Y.H., Blanco J.A., Roy S. (Eds.) Biodiversity in Ecosystems: Linking structure and function. InTech. Rijeka. Pp. 143-167. ISBN 978-953-51-2028-5.

Lo Y.H., Blanco J.A., González de Andrés E., Imbert J.B., Castillo F.J. 2019. CO2 fertilization plays a minor role in long-term carbon accumulation patterns in temperate pine forests in the Pyrenees. Ecological Modelling 407, 108737.

Lo Y.H., Blanco J.A., Welham C., Wang M. 2015. Maintaining Ecosystem Function by Restoring Forest Biodiversity: Reviewing Decision-Support Tools that link Biology, Hydrology and Geochemistry. In Lo Y.H., Blanco J.A., Roy S. (Eds.) Biodiversity in Ecosystems: Linking structure and function. InTech. Rijeka. 
Locatelli, T., Gardiner, B., Tarantola, S., Nicoll, B., Bonnefond, J.-M., Garrigou, D., Kamimura, K., Patenaude, G., 2016. Modelling wind risk to Eucalyptus globulus (Labill.) stands. For. Ecol. Manag. 365, $159 \mathrm{e} 173$.

Locatelli, T., Tarantola, S., Gardiner, B., Patenaude, G. 2017. Variance-based sensitivity analysis of a wind risk model—Model behaviour and lessons for forest modelling. Environ. Modell. Softw. 2017, 87, 84109

Ma, P., Han, X.-H., Lin, Y., Moore, J., Guo, Y.-X., Yue, M., 2019. Exploring the relative importance of biotic and abiotic factors that alter the self-thinning rule: Insights from individual-based modelling and machine learning. Ecol. Model. 397, 16-24.

Marchi, M., Sinjur, I., Bozzano, M., Westergren, M., 2019. Evaluating WorldClim Version 1 (1961-1990) as the Baseline for Sustainable Use of Forest and Environmental Resources in a Changing Climate. Sustainability 11, 3043.

Mateo, R.G., Gaston, A., Jose Aroca-Fernandez, M., Saura, S., Ignacio Garcia-Vinas, J., 2018. Optimization of forest sampling strategies for woody plant species distribution modelling at the landscape scale. For. Ecol. Manag. 410, 104-113.

Mateo, R.G., Jose Aroca-Fernandez, M., Gaston, A., Gomez-Rubio, V., Saura, S., Ignacio Garcia-Vinas, J., 2019. Looking for an optimal hierarchical approach for ecologically meaningful niche modelling. Ecol. Model. 409, 108735.

Mathys, A.S., Coops, N.C., Simard, S.W., Waring, R.H., Aitken, S.N. 2018. Diverging distribution of seedlings and mature trees reflects recent climate change in British Columbia. Ecological Modelling 364, 145-153.

McKenzie, P.F., Duveneck, M.J., Morreale, L.L., Thompson, J.R. 2019. Local and global parameter sensitivity within an ecophysiologically based forest landscape model. Environmental Modelling and Software 117, 1-13.

Mensah, S., Pienaar, O.L.,, Kunneke, A., du Toit, B., Seydack, A., Uhl, E., Pretzsch, H., Seifert, T. 2018. Height-diameter allometry in South Africa's indigenous high forests: assessing generic models performance and function forms. Forest Ecology and Management 410, 1-11.

Meyer, H., Reudenbach, C., Woellauer, S., Nauss, T., 2019. Importance of spatial predictor variable selection in machine learning applications - Moving from data reproduction to spatial prediction. Ecol. Model. 411, 108815.

Miquelajauregui, Y., Cumming, S.G., Gauthier, S. 2019. Short-term responses of boreal carbon stocks to climate change: a simulation study of black spruce forests. Ecological Modelling 409, 108754.

Mitchell, S.J., Hailemariam, T., Kulis, Y., 2001. Empirical modelling of cutblock edge windthrow risk on Vancouver Island, Canada, using stand level information. For. Ecol. Manage. 154, 117-130

Mohan, M., Araujo, B., Mendonça, B., Silva, C. Klauberg, C., Ribeiro, A., Araújo, E., Monte, M.. Cardil, A. 2019. Optimizing individual tree detection accuracy and measuring forest uniformity in coconut (Cocos nucifera L.) plantations using airborne laser scanning. Ecological Modelling. 409. 10.1016.

Molina J.R., Lora, A., Prades, C., Rodríguez y Silva, F. 2019. Roadside vegetation planning and coservation: new approach to prevent and mitigate wildfires based on fire ignition potential. Forest Ecology and Management 444, 163-173. 
Monedero, S., Ramirez, J., Cardil, A. 2019. Predicting fire spread and behaviour on the fireline. Wildfire analyst pocket: A mobile app for wildland fire prediction. Ecol. Model. 392, 103-107.

Moudry, V., Lecours, V., Gdulova, K., Gabor, L., Moudra, L., Kropacek, J., Wild, J., 2018. On the use of global DEMs in ecological modelling and the accuracy of new bare-earth DEMs. Ecol. Model. 383, 3-9.

Navarro-Cerrillo, R.M., Varo-Martinez, M.A., Acosta, C., Palacios Rodriguez, G., Sanchez-Cuesta, R., Gomez, F.J.R., 2019. Integration of WorldView-2 and airborne laser scanning data to classify defoliation levels in Quercus ilex L. Dehesas affected by root rot mortality: Management implications. For. Ecol. Manag. 451, 117564.

Oliver, C.D., Larson, B.C., 1996. Forest Stand Dynamics. McGraw-Hill, New York.

Pascual, A., Bravo, F., Ordonez, C., 2019. Assessing the robustness of variable selection methods when accounting for co-registration errors in the estimation of forest biophysical and ecological attributes. Ecol. Model. 403, 11-19.

Pavão, D.C., Elias, R.B., Silva, L. 2019. Comparison of discrete and continuum community models: insigths from numerical ecology and Bayesian methods applied to Azoran plant communities. Ecological Modelling 402. 93-106.

Pecchi, M., Marchi, M., Burton, V., Giannetti, F., Moriondo, M., Bernetti, I., Bindi, M., Chirici, G., 2019. Species distribution modelling to support forest management. A literature review. Ecol. Model. 411, 108817.

Pelletier, J., Chidumayo, E., Trainor, A., Siampale, A., Mbindo, K., 2019. Distribution of tree species with high economic and livelihood value for Zambia. For. Ecol. Manag. 441, 280-292.

Phua, M.H., Johari, S.A., Wong, O.C., Ioki, K., Mahali, M., Nilus, R., Coomes, D.A., Maycock, C.R., Hashim, M. 2017. Synergistic use of Landsat 8 OLI image and airborne LiDAR data for above-ground biomass estimation in tropical lowland rainforests. For. Ecol. Manag. 406, 163-171.

Piponiot, C., Derroire, G., Descroiz, L., MAzzei, L., Rutishauser, E., Sist, P., Hérault, B. 2018. Assessing timber volumen recovery after disturbance in tropical forests - a new modelling framework, Ecological Modeling 383, 353-369.

Popper, K.R. 1968. Science: conjectures and refutations. Harper \& Row, New York.

Prada, M., González-García, M., Majada, J., Martínez-Alonso, C. 2019. Development of a dynamic growth model for sweet chestnut coppice: a case study in Northwest Spain. Ecological Modelling 409, 108761.

Reise, J., Kukulka, F., Flade, M., Winter, S., 2019. Characterising the richness and diversity of forest bird species using National Forest Inventory data in Germany. For. Ecol. Manag. 432, 799-811.

Resquin, F., Navarro-Cerrillo, R.M., Rachid-Casnati, C., Hirigoyen, A., Carracsco-Letelier, L., Duque-Lazo, J. 2018. Allometry, growth and survival of three Eucalyptus species (eucalyptus benthamii Maiden and Cambage, E. dunnii Maiden and E. grandes Hill ex Maiden) in high-density plantations in Uruguay. Forests, 9,715.

Rich, R.L., Frelich, L.E., Reich, P.B., 2007. Wind-throw mortality in the southern boreal forest: effects of species, diameter and stand age. J. Ecol. 95, 1261-1273.

Roxburgh, S.H., Karunaratne, S.B., Paul, K.I., Lucas, R.M., Armston, J.D., Sun, J., 2019. A revised aboveground maximum biomass layer for the Australian continent. For. Ecol. Manag. 432, 264-275. 
Ruffault, J., Mouillot, F. 2017. Contribution of human and biophysical factors to the spatial distribution of forest fire ignitions an dlarge wildfires in a French Mediterranean region. International Journal of Wildland Fire 26, 498-508.

Ruiz-Benito, P., Vacchiano, G., Lines, E.R., Reyer, C.P.O., Ratcliffe, S., Morin, X., Hartig, F., Mäkelä, A., Yousefpour, R., Chaves, J.E., Palacios-Orueta, A., Benito-Garzón, M., Morales-Molino, C., Camarero, J.J., Jump, A.S., Kattge, J., Lehtonen, A., Ibrom, A., Owen, H.J.F., Zavala, M.A., 2020. Available and missing data to model impact of climate change on European forests. Ecol. Model. 416, 108870.

Savage, S. L., Lawrence, RL., Squires, JR. 2017. Mapping post-disturbance forest landscape composition with Landsat satellite imagery. For. Ecol. Manag. 399, 9-23.

Schratz, P., Muenchow, J., Iturritxa, E., Richter, J., Brenning, A., 2019. Hyperparameter tuning and performance assessment of statistical and machine-learning algorithms using spatial data. Ecol. Model. 406, 109-120.

Seidl, R. et al. 2011. Modelling natural disturbances in forest ecosystems: a review. Ecol. Model. 222, 903924

Sherman, T., J.M. Varner, S.M. Hood, C.A. Cansler, J.K. Hiers. 2019. Modelling post-fire tree mortality: Can random forest improve discrimination of imbalanced data? Submitted to Ecological Modeling. Ecological Modelling $414-108855$

Shi, Y., Xu, L., Zhou, Y., Ji, B., Zhou, G., Fang, H., Yin, J., Deng, X., 2018. Quantifying driving factors of vegetation carbon stocks of Moso bamboo forests using machine learning algorithm combined with structural equation model. For. Ecol. Manag. 429, 406-413.

Shirk, A.J., Cushman, S.A., Waring, K.M., Wehenkel, C.A., Leal-Saenz, A., Toney, C., Lopez-Sanchez, C.A., 2018. Southwestern white pine (Pinus strobiformis) species distribution models project a large range shift and contraction due to regional climatic changes. For. Ecol. Manag. 411, 176-186.

Smigaj, M., Gaulton, R., Suarez, J. C., and Barr, S. L. 2019. Canopy temperature from an unmanned aerial vehicle as an indicator of tree stress associated with red band needle blight severity. For. Ecol. Manage. 433, 699-708.

Song, Y.-G., Petitpierre, B., Deng, M., Wu, J.-P., Kozlowski, G., 2019. Predicting climate change impacts on the threatened Quercus arbutifolia in montane cloud forests in southern China and Vietnam: Conservation implications. For. Ecol. Manag. 444, 269-279.

Soto, D.P., Puettmann, K.J., Fuentes, C., Jacobs, D.F., 2019. Regeneration niches in Nothofagus-dominated old-growth forests after partial disturbance: Insights to overcome arrested succession. For. Ecol. Manag. $445,26-36$.

Srivastava, V., Griess, V.C., Padalia, H., 2018. Mapping invasion potential using ensemble modelling. A case study on Yushania maling in the Darjeeling Himalayas. Ecol. Model. 385, 35-44.

Suárez-Muñoz, M., Bonet-García, F., Hódar, J. A., Herrero, J., Tanase, M., \& Torres-Muros, L. 2019. INSTAR: An Agent-Based Model that integrates existing knowledge to simulate the population dynamics of a forest pest. Ecological Modelling, 411, 108764

Sullivan FB, Palace MW, Ducey MJ, Orwig DA, Cook B. 2017 Comparison of lidar canopy height model and allometry-derived canopy height models in an eastern deciduous forest. Forest Ecol. Manag. 406, 83 -94 . 
Suvanto, S., Peltoniemi, M., Tuominen, S., Strandström, M., Lehtonen, A., 2019. High-resolution mapping of forest vulnerability to wind for disturbance-aware forestry, Forest Ecology and Management, Volume 453

Talucci, A.C., Lertzman, K.P., Krawchuk, M.A. 2019. Drivers of lodgepole pine recruitment across a gradient of bark beetle outbreak and wildfire in British Columbia. Forest Ecology and Management 451, 117500 .

Talluto, M.V., Boulangeat, I., Ameztegui, A., Aubin, I., Berteaux, D., Butler, A., Doyon, F., Drever, C.R., Fortin, M.-J., Franceschini, T., Liénard, J., McKenney, D., Solarik, K.A., Strigul, N., Thuiller, W., Gravel, D., 2016. Cross-scale integration of knowledge for predicting species ranges: a metamodelling framework. Glob. Ecol. Biogeogr. 25, 238-249.

Thom, D., Keeton, W.S., 2019. Stand structure drives disparities in carbon storage in northern hardwoodconifer forests. For. Ecol. Manag. 442, 10-20.

Thurm, E.A., Hernandez, L., Baltensweiler, A., Ayan, S., Rasztovits, E., Bielak, K., Zlatanov, T.M., Hladnik, D., Balic, B., Freudenschuss, A., Buechsenmeister, R., Falk, W., 2018. Alternative tree species under climate warming in managed European forests. For. Ecol. Manag. 430, 485-497.

Urban D.L. 2005. Modeling ecological processes across scales. Ecology 86(8), 1996-2006.

Valbuena, R., Hernando, A., Manzanera, J.A., Görgens, E.B., Almeida, D.R.A., Mauro, F., García-Abril, A., Coomes, D.A., 2017. Enhancing of accuracy assessment for forest above-ground biomass estimates obtained from remote sensing via hypothesis testing and overfitting evaluation. Ecol. Model. 366, 15-26.

Van der Vyver, M.L., Cowling, R.M. 2019. Aboveground biomass and carbon pool estimates of Portulacaria afra (spekboom)-rich subtropical thicket with species-specific allometric models. Forest Eoclogy and Management 448, 11-21.

Van Vinh, T., Marchand, C., Linh, T.V.K., Vinh, D.D., Allenbach, M. 2019. Allometric models to estimate above-ground biomass and carbon stocks in Rhiziphora apiculata tropical mangrove forests (Southern Viet Nam). Forest Ecology and Management 434, 131-141.

Vergarechea, M., Calama, R., Fortin, M., Del Río, M. Climate-mediated regeneration occurrence in Mediterranean pine forests: a modeling approach. Forest Ecology and Management 446, 10-19.

Wei X., Blanco J.A. 2014. Significant increase in forest carbon can be achieved by implementing sustainable forest management. PLoS ONE 9(2): e89688.

Wiggins, H.L., Nelson, C.R., Larson, A.J., Safford, H.D. 2019. Using LiDAR to develop high-resolution reference models of forest structure and spatial pattern. Ecol. Manag. 434, 318-330.

Xie, Y., Wang, H., Lei, X. 2017. Application of the 3-PG model to predict growth of Larix olgensis plantaiton sin northeastern China.

Ying, L., Han, J., Du, Y., Shen, Z., 2018. Forest fire characteristics in China: Spatial patterns and determinants with thresholds. For. Ecol. Manag. 424, 345-354.

Zheng J., Blanco J.A., Wei X., Liu C. 2018. Sustainable management of Metasequoia glyptostroboides plantation forests in Shanghai. Forests, 9(2), 64.

Zhang, Q., He, H.S., Liang, Y., Hawbaker, T.J., Henne, P.D., Liu, J., Huang, S., Wu, Z., Huang, C., 2018. Integrating forest inventory data and MODIS data to map species-level biomass in Chinese boreal forests. Can. J. For. Res. 48, 461-479. 
Zhao, Q., Yu, S., Zhao, F., Tian, L., Zhao, Z., 2019. Comparison of machine learning algorithms for forest parameter estimations and application for forest quality assessments. For. Ecol. Manag. 434, 224-234.

Zhu, Y., Liu, Z., Jin, G. 2019. Evaluating individual-based tree mortality modeling with temporal observation data collected from a large forest plot. Forest Ecology and Management 450, 117496. 
Table 1. A selection of published references using forest models during the period $2017-2019$.

References in bold are published in this special issue. See text for the method used to identify these sources.

\begin{tabular}{|c|c|c|c|c|c|}
\hline Reference & $\begin{array}{l}\text { Main target } \\
\text { variables }\end{array}$ & Spatial scale & Model type & Forest type & $\begin{array}{l}\text { Region of } \\
\text { application }\end{array}$ \\
\hline Correia et al. 2018 & Biomass & Individual trees & Empirical - Allometric & Mediterranean & Europe \\
\hline Falloye et al. 2018 & Biomass & Individual trees & Empirical - Allometric & Tropical & Africa \\
\hline Forrester et al. 2017 & Biomass & Individual trees & Empirical - Allometric & Temperate & Europe \\
\hline Fu et al. 2017 & Biomass & Individual trees & Empirical - Allometric & Temperate & Asia \\
\hline Mensah et al. 2018 & Biomass & Individual trees & Empirical - Allometric & Temperate & Africa \\
\hline $\begin{array}{l}\text { Van der Vyyer and } \\
\text { Cowling } 2019\end{array}$ & Biomass & Individual trees & Empirical - Allometric & Subtropical & Africa \\
\hline Armstrong et al. 2018 & Biomass & Individual trees & Process based & Tropical & Africa \\
\hline Brubaker et al. 2018 & Biomass & Landscape & Empirical - Random Forest & Temperate & North America \\
\hline $\begin{array}{l}\text { Corona-Nuñez et al. } \\
2017\end{array}$ & Biomass & Landscape & Empirical - Random Forest & Tropical & North America \\
\hline Zhang et al. 2018 & Biomass & Landscape & Empirical - Random Forest & Boreal & Asia \\
\hline Huang et al. 2018 & Biomass & Landscape & Process based & Temperate & North America \\
\hline Prada et al. 2019 & Biomass & Stand / Gap & Empirical - Others & Temperate & Europe \\
\hline Khan et al. 2018 & Carbon pools & Individual trees & Empirical - Allometric & Tropical & Asia \\
\hline Roxburgh et el. 2019 & Carbon pools & Individual trees & Process based & Temperate & Oceania \\
\hline Shi et al. 2018 & Carbon pools & Landscape & Empirical - Random Forest & Subtropical & Asia \\
\hline $\begin{array}{l}\text { Thom and Keeton } \\
2019\end{array}$ & Carbon pools & Landscape & Empirical - Random Forest & Temperate & North America \\
\hline Phua et al. 2017 & Carbon pools & Regional & Empirical - Remote sensing & Tropical & Asia \\
\hline Chen et al.2019 & Carbon pools & Stand / Gap & $\begin{array}{l}\text { Empirical - Machine } \\
\text { learning }\end{array}$ & Temperate & Asia \\
\hline Chen et al. 2018 & Carbon pools & Stand / Gap & Empirical - Remote sensing & Temperate & Asia \\
\hline Lo et al. 2019 & Carbon pools & Stand / Gap & Hybrid & Multiple & Europe \\
\hline $\begin{array}{l}\text { Miquelajáuregui et } \\
\text { al. } 2019\end{array}$ & Carbon pools & Stand / Gap & Process based & Boreal & North America \\
\hline Gómez-Sanz 2019 & $\begin{array}{l}\text { Density / stand } \\
\text { dynamics }\end{array}$ & Individual trees & Empirical - Others & Mediterranean & Europe \\
\hline Kralicek et al. 2018 & $\begin{array}{l}\text { Density / stand } \\
\text { dynamics }\end{array}$ & Individual trees & Empirical - Others & Temperate & North America \\
\hline $\begin{array}{l}\text { Vergarechea et al. } \\
2019\end{array}$ & $\begin{array}{l}\text { Density / stand } \\
\text { dynamics }\end{array}$ & Individual trees & Empirical - Others & Mediterranean & Europe \\
\hline Honkaniemi et al. 2018 & $\begin{array}{l}\text { Density / stand } \\
\text { dynamics }\end{array}$ & Individual trees & Process based & Boreal & Europe \\
\hline Zhu et al. 2019 & $\begin{array}{l}\text { Density / stand } \\
\text { dynamics }\end{array}$ & Individual trees & Process based & Temperate & Asia \\
\hline $\begin{array}{l}\text { Dyderski and } \\
\text { Jagodzinski } 2019\end{array}$ & $\begin{array}{l}\text { Density / stand } \\
\text { dynamics }\end{array}$ & Landscape & $\begin{array}{l}\text { Empirical - Machine } \\
\text { learning }\end{array}$ & Temperate & Europe \\
\hline Gill et al. 2017 & $\begin{array}{l}\text { Density / stand } \\
\text { dynamics }\end{array}$ & Landscape & Empirical - Others & Temperate & North America \\
\hline $\begin{array}{l}\text { Fernández-Guisuaraga } \\
\text { et al. } 2019\end{array}$ & $\begin{array}{l}\text { Density / stand } \\
\text { dynamics }\end{array}$ & Landscape & Empirical - Remote sensing & Temperate & Europe \\
\hline McKenzie et al. 2019 & $\begin{array}{l}\text { Density / stand } \\
\text { dynamics }\end{array}$ & Landscape & Process based & Temperate & North America \\
\hline Foster et al. 2019 & $\begin{array}{l}\text { Density / stand } \\
\text { dynamics }\end{array}$ & Regional & Process based & Boreal & North America \\
\hline Andrews et al 2018 & $\begin{array}{l}\text { Density / stand } \\
\text { dynamics }\end{array}$ & Stand / Gap & Empirical - Allometric & Temperate & North America \\
\hline $\begin{array}{l}\text { Dïaz-Yáñez et al. } \\
2019\end{array}$ & $\begin{array}{l}\text { Density / stand } \\
\text { dynamics }\end{array}$ & Stand / Gap & $\begin{array}{l}\text { Empirical - Machine } \\
\text { learning }\end{array}$ & Boreal & Europe \\
\hline Pavão et al. 2019 & $\begin{array}{l}\text { Density / stand } \\
\text { dynamics }\end{array}$ & Stand / Gap & $\begin{array}{l}\text { Empirical - Machine } \\
\text { learning }\end{array}$ & Temperate & Europe \\
\hline Schratz et al. 2019 & $\begin{array}{l}\text { Density / stand } \\
\text { dynamics }\end{array}$ & Stand / Gap & $\begin{array}{l}\text { Empirical - Machine } \\
\text { learning }\end{array}$ & Temperate & Europe \\
\hline Canelles et al. 2019 & $\begin{array}{l}\text { Density / stand } \\
\text { dynamics }\end{array}$ & Stand / Gap & Empirical - Others & Mediterranean & Europe \\
\hline
\end{tabular}




\begin{tabular}{|c|c|c|c|c|c|}
\hline Ma et al. 2019 & $\begin{array}{l}\text { Density / stand } \\
\text { dynamics }\end{array}$ & Stand / Gap & Empirical - Random Forest & Temperate & Multiple \\
\hline Valbuena et al. 2017 & $\begin{array}{l}\text { Density / stand } \\
\text { dynamics }\end{array}$ & Stand / Gap & Empirical - Remote sensing & Temperate & Europe \\
\hline Mathys et al. 2018 & $\begin{array}{l}\text { Density / stand } \\
\text { dynamics }\end{array}$ & Stand / Gap & Hybrid & Temperate & North America \\
\hline Ameztegui et al. 2017 & $\begin{array}{l}\text { Density / stand } \\
\text { dynamics }\end{array}$ & Stand / Gap & Process based & Temperate & Europe \\
\hline Barnes et al. 2017 & Forest disturbances & Individual trees & Empirical - Remote sensing & Temperate & Europe \\
\hline Klauberg et al. 2019 & Forest disturbances & Individual trees & $\begin{array}{l}\text { Empirical - Remote } \\
\text { sensing }\end{array}$ & Temperate & North America \\
\hline $\begin{array}{l}\text { Navarro-Cerrillo et al. } \\
2019\end{array}$ & Forest disturbances & Individual trees & Empirical - Remote sensing & Mediterranean & Europe \\
\hline Smigaj et al. 2019 & Forest disturbances & Individual trees & Empirical - Remote sensing & Temperate & Europe \\
\hline Cardil et al. 2019b & Forest disturbances & Individual trees & Process based & Tropical & Africa \\
\hline Cruz et al. 2018 & Forest disturbances & Landscape & Empirical - Others & Temperate & Oceania \\
\hline Cardil et al. 2019a & Forest disturbances & Landscape & Empirical - Random Forest & Boreal & North America \\
\hline $\begin{array}{l}\text { García-Llamas et al. } \\
2019\end{array}$ & Forest disturbances & Landscape & Empirical - Random Forest & Temperate & Europe \\
\hline $\begin{array}{l}\text { García-Llamas et al. } \\
2019 b\end{array}$ & Forest disturbances & Landscape & Empirical - Random Forest & Temperate & Europe \\
\hline Liang et al. 2017 & Forest disturbances & Landscape & Empirical - Remote sensing & Temperate & North America \\
\hline Monedero et al. 2019 & Forest disturbances & Landscape & $\begin{array}{l}\text { Empirical - Remote } \\
\text { sensing }\end{array}$ & Temperate & Europe \\
\hline $\begin{array}{l}\text { Ruffaut and Mouillot } \\
2017\end{array}$ & Forest disturbances & Landscape & Hybrid & Mediterranean & Europe \\
\hline Clements et al. 2019 & Forest disturbances & Landscape & Process based & Subtroprical & North America \\
\hline Sherman et al. 2019 & Forest disturbances & Regional & $\begin{array}{l}\text { Empirical - Machine } \\
\text { learning }\end{array}$ & Temperate & North America \\
\hline Boulanger et al. 2018 & Forest disturbances & Regional & Empirical - Others & Boreal & North America \\
\hline Locatelli et al. 2016 & Forest disturbances & Regional & Empirical - Others & Temperate & Europe \\
\hline Locatelli et al. 2017 & Forest disturbances & Regional & Empirical - Others & Temperate & Europe \\
\hline Iacopetti et al. 2019 & Forest disturbances & Regional & Empirical - Random Forest & Mediterranean & Europe \\
\hline Ying et al. 2018 & Forest disturbances & Regional & Empirical - Random Forest & Temperate & Asia \\
\hline Barker et al.2019 & Forest disturbances & Stand / Gap & Empirical - Allometric & Temperate & North America \\
\hline Suvanto et al. 2019 & Forest disturbances & Stand / Gap & $\begin{array}{l}\text { Empirical - Machine } \\
\text { learning }\end{array}$ & Boreal & Europe \\
\hline Grayson et al. 2017 & Forest disturbances & Stand / Gap & Empirical - Others & Temperate & North America \\
\hline Koch et al. 2018 & Forest disturbances & Stand / Gap & Empirical - Others & Temperate & North America \\
\hline Molina et al. 2019 & Forest disturbances & Stand / Gap & Empirical - Others & Mediterranean & Europe \\
\hline Talluci et al. 2019 & Forest disturbances & Stand / Gap & Empirical - Others & Boreal & North America \\
\hline $\begin{array}{l}\text { Leuenberger et al. } \\
2018\end{array}$ & Forest disturbances & Stand / Gap & Empirical - Random Forest & Temperate & Europe \\
\hline Chen et al. 2017 & Forest disturbances & Stand / Gap & Empirical - Remote sensing & Temperate & Oceania \\
\hline Savage et al. 2017 & Forest disturbances & Stand / Gap & Empirical - Remote sensing & Temperate & North America \\
\hline Faeth et al. 2019 & Nutrient flows & Continental & $\begin{array}{l}\text { Empirical - Machine } \\
\text { learning }\end{array}$ & Temperate & Europe \\
\hline Kamoske et al. 2019 & Nutrient flows & Individual trees & Empirical - Remote sensing & Temperate & North America \\
\hline $\begin{array}{l}\text { González de Andrés et } \\
\text { al. } 2017\end{array}$ & Nutrient flows & Stand / Gap & Hybrid & Yediterranean & Europe \\
\hline Zheng et al. 2018 & Nutrient flows & Stand / Gap & Hybrid & Subtropical & Asia \\
\hline Krebs et al. 2017 & Others / multiple & Individual trees & Empirical - Others & Boreal & North America \\
\hline Li et al. 2019 & Others / multiple & Individual trees & Empirical - Others & Multiple & Multiple \\
\hline Kumar et al. 2019 & Others / multiple & Individual trees & Process based & Temperate & Asia \\
\hline $\begin{array}{l}\text { Suárez-Muñoz et al. } \\
2019\end{array}$ & Others / multiple & Individual trees & Pro & Mediterranean & Africa \\
\hline Zhao et al. 2019 & Others / multiple & Regional & $\begin{array}{l}\text { Empirical - Machine } \\
\text { learning }\end{array}$ & Temperate & Asia \\
\hline Krebs et al. 2019 & Others / multiple & Regional & Empirical - Random Forest & Temperate & North America \\
\hline Reise et al. 2019 & Others / multiple & Regional & Empirical - Random Forest & Temperate & Europe \\
\hline $\begin{array}{l}\text { Kupferschmid et al. } \\
2019\end{array}$ & Others / multiple & Stand / Gap & Empirical - Random Forest & Temperate & Europe \\
\hline Affleck 2019 & $\begin{array}{l}\text { Productivity (GPP } \\
\text { NPP NEE) }\end{array}$ & Individual trees & Empirical - Allometric & Temperate & North America \\
\hline
\end{tabular}




\begin{tabular}{|c|c|c|c|c|c|}
\hline $\begin{array}{l}\text { Castaño-Santamaría et } \\
\text { al. } 2019\end{array}$ & $\begin{array}{l}\text { Productivity (GPP } \\
\text { NPP NEE) }\end{array}$ & Landscape & Empirical - Remote sensing & Temperate & Europe \\
\hline Dury et al. 2019 & $\begin{array}{l}\text { Productivity (GPP } \\
\text { NPP NEE) }\end{array}$ & Regional & Process based & Tropical & Africa \\
\hline Han et al. 2018 & $\begin{array}{l}\text { Productivity (GPP } \\
\text { NPP NEE) }\end{array}$ & Regional & Process based & Temperate & Europe \\
\hline Piponiot et al. 2018 & $\begin{array}{l}\text { Productivity (GPP } \\
\text { NPP NEE) }\end{array}$ & Stand / Gap & Empirical - Others & Tropical & South America \\
\hline $\begin{array}{l}\text { Hawrylo and Wezyk } \\
2018\end{array}$ & $\begin{array}{l}\text { Productivity (GPP } \\
\text { NPP NEE) }\end{array}$ & Stand / Gap & Empirical - Remote sensing & Temperate & Europe \\
\hline Meyer et al. 2018 & $\begin{array}{l}\text { Productivity (GPP } \\
\text { NPP NEE) }\end{array}$ & Stand / Gap & Process based & Temperate & North America \\
\hline $\begin{array}{l}\text { Djomo and Chimi } \\
2017\end{array}$ & $\begin{array}{l}\text { Size (DBH Height } \\
\text { BA) }\end{array}$ & Individual trees & Empirical - Allometric & Tropical & Africa \\
\hline Resquin et al. 2018 & $\begin{array}{l}\text { Size (DBH Height } \\
\text { BA) }\end{array}$ & Individual trees & Empirical - Allometric & Temperate & South America \\
\hline Pascual et al. 2019 & $\begin{array}{l}\text { Size (DBH Height } \\
\text { BA) }\end{array}$ & Individual trees & $\begin{array}{l}\text { Empirical - Random } \\
\text { Forest }\end{array}$ & Mediterranean & Europe \\
\hline Mohan et al. 2019 & $\begin{array}{l}\text { Size (DBH Height } \\
\text { BA) }\end{array}$ & Individual trees & $\begin{array}{l}\text { Empirical - Remote } \\
\text { sensing }\end{array}$ & Tropical & South America \\
\hline Brazhnik et al. 2017 & $\begin{array}{l}\text { Size (DBH Height } \\
\text { BA) }\end{array}$ & Individual trees & Process based & Boreal & Asia \\
\hline Xie et al. 2019 & $\begin{array}{l}\text { Size (DBH Height } \\
\text { BA) }\end{array}$ & Individual trees & Process based & Temperate & Asia \\
\hline Sullivan et al. 2017 & $\begin{array}{l}\text { Size (DBH Height } \\
\text { BA) }\end{array}$ & Stand / Gap & Empirical - Allometric & Temperate & North America \\
\hline Van Vinh et al. 2019 & $\begin{array}{l}\text { Size (DBH Height } \\
\text { BA) }\end{array}$ & Stand / Gap & Empirical - Allometric & Tropical & Asia \\
\hline Wiggins et al. 2019 & $\begin{array}{l}\text { Size (DBH Height } \\
\text { BA) }\end{array}$ & Stand / Gap & Empirical - Remote sensing & Temperate & North America \\
\hline Li et al. 2018 & Species distribution & Continental & Empirical - Others & Temperate & Multiple \\
\hline Thurm et al. 2018 & Species distribution & Continental & Empirical - Others & Temperate & Europe \\
\hline Talluto et al. 2016 & Species distribution & Continental & Hybrid & Temperate & North America \\
\hline Arieira et al. 2018 & Species distribution & Landscape & Empirical - Others & Subtropical & South America \\
\hline Pecchi et al., 2019 & Species distribution & Regional & Empirical - Others & Multiple & Multiple \\
\hline Pelletier et al., 2019 & Species distribution & Regional & Empirical - Others & Subtropical & Africa \\
\hline Shirk et al. 2018 & Species distribution & Regional & Empirical - Others & Temperate & North America \\
\hline Song et al., 2019 & Species distribution & Regional & Empirical - Others & Temperate & Asia \\
\hline Srivastava et al., 2018 & Species distribution & Regional & Empirical - Others & Alpine & Asia \\
\hline Koo et al., 2017b & Species distribution & Regional & Empirical - Random Forest & Temperate & Asia \\
\hline Giménez et al. 2019 & Water flows & Stand / Gap & Empirical - Others & Temperate & Europe \\
\hline Attia et al. 2019 & Water flows & Stand / Gap & Process based & Tropical & South America \\
\hline
\end{tabular}

